\title{
PERANCANGAN SISTEM PELAYANAN RESTORAN BERBASIS WEB MOBILE MENGGUNAKAN FRAMEWORK YII2
}

\author{
Maharani Hamidah' ${ }^{1}$, Geovanne Farell ${ }^{2}$ \\ ${ }^{1,2}$ Prodi Pendidikan Teknik Informatika, Fakultas Teknik, Universitas Negeri Padang \\ Email : ${ }^{1}$ chaniagomaharani@gmail.com, ${ }^{2}$ geovannefarell@ft.unp.ac.id
}

\begin{abstract}
The increased business needs and rapid technological developments helped to make easier in marketing, ordering, or delivery. Restaurant service that is still manual is only efficient for visitors who are few. With a-based restaurant application it mobile web will make it easier and more efficient for large restaurants with more visitors. With reliable Smartphone, visitors immediately place an order through the waterfall method and database MySQL, so that later it will produce an application that is accessed via a Smartphone customer in handling food menu orders.
\end{abstract}

Keywords : Restaurant, Business, Framework Yii2, Waterfall.

\section{INTISARI}

Kebutuhan bisnis yang semakin banyak dan perkembangan teknologi yang pesat membantu memudahkan dalam memasarkan, pemesanan, ataupun delivery. Layanan restoran yang masih manual hanya efisien pada pengunjung yang sedikit. Dengan adanya aplikasi restoran berbasis web mobile akan lebih memudahkan serta efisien pada restoran yang besar dengan pengunjung yang lebih banyak. Dengan mengandalkan smartphone, pengunjung langsung melakukan pemesanan melalui browser yang tersedia. Pada penelitian ini, aplikasi restoran dirancang menggunakan framework Yii2 dengan metode waterfall dan database MySQL, sehingga nantinya akan menghasilkan sebuah aplikasi yang diakses melalui smartphone customer dalam penanganan order menu makanan.

Kata Kunci : Restoran, Bisnis, Framework Yii2, Waterfall.

\section{PENDAHULUAN}

Dewasa ini, pesatnya perkembangan teknologi menjadikan pemenuhan kebutuhan bisnis semakin memudahkan para entrepreneur. Peran teknologi saat ini sangat berpengaruh pada perkembangan bisnis, informasi dan teknologi diterapkan pada sebuah restoran akan membantu, memudahkan dan mempercepat pelayanan operasional terutama proses pemesanan makanan serta minuman, sehingga lebih terlihat efektif dan efisien. Kemampuan teknologi dalam mengkoordinir pelayanan sebuah restoran adalah salah satu peran teknologi.

Perkembangan informasi kian merambat ke area digital, yaitu informasi yang awalnya diolah secara konvensional dengan menggunakan penyimpanan berupa buku (paper based), kini dengan adanya teknologi komputer informasi dikelola dan disimpan dalam bentuk file digital [1].

Bisnis restoran sudah semakin banyak dan berkemang. Semakin banyak pula variasi makanan yang dapat menjadi daya tarik pada makanan yang dapat menjadi daya tarik pada setiap restoran. Pesanan yang dilakukan secara manual, yaitu dengan mencatat menu pilihan customer/pelanggan satu persatu. Hal ini akan mudah jika diterapkan untuk restooran berskala kecil dengan pelanggan yang sedikit, namun akan tidak efektif dan tidak efisien jika penerapannya 
pada restoran yang sudah memiliki pengunjung yang cukup tinggi.

Restoran yang memiliki pengunjung yang relatif ramai, pelayanan akan menjadi terlihat buruk jika semua waiters sibuk melayani dan membuat pelanggan yang baru datang merasa terabaikan, baik dalam ha pemilihan kursi dan meja makan yang masih kosong akan semakin sulit. Untuk membantu pelanggan/pengunjung memudahkan dalam memilih kursi dan meja yang kosong, akan dirancang sebuah aplikasi pelayanan restoran dengan fitu dapat melihat meja yang sudah terisi dan masih kosong. Fitur memilih menu makanan serta minuman juga akan disediakan pada aplikasi pelayanan restoran. Dengan menggunakan aplikasi ini pengunjung yang baru akan merasa tidak diabaikan jika kursi dan meja yang telah penuh karena dapat melihat kursi dan meja yang tersedia pada restoran tersebut masih ada yang kosong atau sudah penuh. Daftar menu makanan dan minuman dilengkapi dengan gambar dan harga serta deskripsi makanan atau minuman. Aplikasi ini dibangun menggunakan framework Yii2 yang sangat responsive tehadap mobile phone.

\section{Yii2 Framework}

Yii merupakan suatu framework php yang memiliki performa mengagumkan untuk merancang sebuah aplikasi web dengan cepat. Yii singkatan dari Yes It Is yang artinya Ya, Itu Dia!. Arsitektur yang digunakan framework yii2 adalah Model-View-Controller berfungsi untuk memudahkan developer dalam memisahkan logika bisnis dan antarmuka pengguna, sehingga lebih mudah melakukan pengubahan tanpa mempengaruhi bagian yang lainnya. Yii2 telah mengadopsi teknologi protokol terbaru, seperti composer, namespace, traits, dan lain-lain. Yii memiliki dukungan authentication(login, logout) dan authorizational(hak akses), sehingga memudahkan developer aplikasi dengan fitur autentikasi. Selain itu yii juga memiliki fitur keamanan yang membantu dalam mencegah serangan-serangan, seperti SQL Injection, XSS, CookieTampering [2].

\section{WEB MOBILE}

Web Mobile merupakan sebuah website dengan interface yang disesuaikan terhadap tampilan mobile. Aplikasi berbasis web mobile sama seperti web pada umumnya hanya saja letak perbedaannya ada pada tampilan ketika web tersebut diakses melalui perangkat portable seperti smartphone atau tablet[3].

\section{MySQL}

MySQL adalah singkatan dari My Structure Query Language, yaitu sistem manajemen basis data SQL yang banyak digunakan karena bersifat gratis di bawah lisensi GNU General Public License (GPL). Selain itu MySQL dapat berjalan dengan stabil pada berbagai sistem operasi, seperti Windows, Linux, Solaris, dan masih banyak lainnya. MySQL memiliki kecepatan yang baik dalam menangani lapisan sekuriti, seperti nama host, level subnet mask, dan izin akses user menggunakan password yang terenkripsi[4].

\section{PENDEKATAN PEMECAHAN MASALAH}

Penelitian ini menerapkan metode waterfall sebagai sebuah model proses pengembangan sistem informasi/perangkat lunak yang sistematik dan sikuensial [5]. Model ini memiliki beberapa tahapan, diantaranya [6] :

1. Analisis Kebutuhan Sistem

Analisis kebutuhan bertujuan untuk mencari kebutuhan dari sistem informasi, semua kebutuhan perlu didapatkan dalam fase ini. Untuk mendapatkan informasi kebutuhan umumnya diperoleh dengan cara wawancara, observasi dan diskusi. Kemudian dianalisis untuk mendapatkan dokumentasi kebutuhan yang akan digunakan pada fase selanjutnya.

2. Desain Sistem

Sebelum melakukan coding, tahap desain sistem bertujuan untuk mendapatkan gambaran yang akan dikerjakan serta tampilannya. Desain sistem berfokus pada empat atribut berbeda dari sebuah program, yaitu arsitektur perangkat lunak, representasi interface, struktur data, dan prosedural rinci yang membantu dalam menspesifikasikan kebutuhan perangkat keras dan sistem. 
3. Pembuatan Kode (Coding)

Desain sistem yang telah dirancang kemudian diterjemahkan ke dalam bentuk bahasa mesin. Pengkodean akan sangat bergantung pada hasil desain.

4. Pengujian(Testing)

Tahap ini akan dilakukan pengujian terhadap sistem. Untuk memastikan kesesuaian coding pada desain sistem, serta menemukan kesalahan dan memastikan input kebutuhan telah sesuai.

\section{HASIL DAN PEMBAHASAN Analisa Sistem}

1. Analisa Masalah dan Solusi

Tabel 1. Analisa Masalah dan Solusi

\begin{tabular}{|c|c|c|}
\hline $\mathrm{NO}$ & Masalah & Solusi \\
\hline 1. & $\begin{array}{l}\text { Sulitnya meneukan } \\
\text { meja yang kosong } \\
\text { akibat pelanggan } \\
\text { yang banyak dan } \\
\text { waiters yang sibuk }\end{array}$ & $\begin{array}{l}\text { Aplikasi ini } \\
\text { memberikan } \\
\text { kemudahan untuk } \\
\text { melihat meja yang } \\
\text { kosong dengan } \\
\text { terlebih dahulu } \\
\text { register ke dalam } \\
\text { sistem. }\end{array}$ \\
\hline 2. & $\begin{array}{l}\text { Pelayanan yang } \\
\text { buruk, jika waiters } \\
\text { terlambat } \\
\text { memberikan daftar } \\
\text { menu kepada } \\
\text { pelanggan/customer } \\
\text { yang datang }\end{array}$ & $\begin{array}{l}\text { Dengan sistem ini } \\
\text { akan memudahkan } \\
\text { pelanggan/customer } \\
\text { dalam memilih dan } \\
\text { melihat daftar menu } \\
\text { yang disediakan oleh } \\
\text { restoran hanya } \\
\text { dengan mengakses } \\
\text { aplikasi restoran. }\end{array}$ \\
\hline 3. & $\begin{array}{l}\text { Pemesanan yang } \\
\text { masih manual }\end{array}$ & $\begin{array}{l}\text { Sistem yang baru } \\
\text { menawarkan } \\
\text { kemandirian } \\
\text { pelanggan dengan } \\
\text { melakukan } \\
\text { pemesanan langsung } \\
\text { menggunakan } \\
\text { ponsel/gadget. }\end{array}$ \\
\hline
\end{tabular}

2. Analisa Sistem yang akan Dikembangkan

Tabel 2. Analisa sistem yang akan dikembangkan

\begin{tabular}{lll}
\hline Masukan & Proses & Keluaran \\
\hline Data menu & Daftar menu & Data menu \\
makanan, & akan dikelola & makanan \\
meliputi & oleh admin, & \\
gambar, & yaitu & \\
deskripsi, nama & memasukkan & \\
\hline
\end{tabular}

\begin{tabular}{|c|c|c|}
\hline $\begin{array}{l}\text { menu, harga, } \\
\text { kategori } \\
\text { makanan. }\end{array}$ & $\begin{array}{l}\text { data menu } \\
\text { makanan yang } \\
\text { disediakan oleh } \\
\text { restoran, yang } \\
\text { terlebih dahulu } \\
\text { admin login } \\
\text { pada sistem. }\end{array}$ & \\
\hline $\begin{array}{l}\text { Input data meja, } \\
\text { meliputi nomor } \\
\text { meja, srta status. }\end{array}$ & $\begin{array}{l}\text { Nomor meja } \\
\text { akan diproses } \\
\text { oleh admin, } \\
\text { yaitu dengan } \\
\text { memasukkan } \\
\text { daftar nomor- } \\
\text { nomor meja } \\
\text { sesuai dengan } \\
\text { meja yang ada } \\
\text { pada restoran. }\end{array}$ & $\begin{array}{l}\text { Data nomor } \\
\text { meja }\end{array}$ \\
\hline $\begin{array}{l}\text { Input kategori } \\
\text { menu, baik sub } \\
\text { kategori dan } \\
\text { jenis kategori, } \\
\text { yang meliputu } \\
\text { nama-nama } \\
\text { kategori serta } \\
\text { pembagiannya, } \\
\text { dan gamba dari } \\
\text { jenis kategori. }\end{array}$ & $\begin{array}{l}\text { Setiap menu } \\
\text { akan dibedakan } \\
\text { berdasarkan } \\
\text { kategorinya, } \\
\text { admin akan } \\
\text { mengentri, } \\
\text { mengubah, dan } \\
\text { menambah } \\
\text { banyak kategori } \\
\text { menu restoran. }\end{array}$ & $\begin{array}{l}\text { Informasi } \\
\text { yang didapat } \\
\text { adalah } \\
\text { mengelompok } \\
\text { kan menu } \\
\text { kedalam } \\
\text { kategori. }\end{array}$ \\
\hline $\begin{array}{l}\text { Input data } \\
\text { pelanggan/ } \\
\text { customer } \\
\text { meliputi nama } \\
\text { pelanggan }\end{array}$ & $\begin{array}{l}\text { Pelanggan akan } \\
\text { mengakses } \\
\text { aplikasi begitu } \\
\text { masuk ke } \\
\text { restoran dan } \\
\text { melakukan } \\
\text { booking meja } \\
\text { dengan } \\
\text { menginputkan } \\
\text { nama terlebih } \\
\text { dahulu untuk } \\
\text { registem ke } \\
\text { sistem. }\end{array}$ & $\begin{array}{l}\text { Data } \\
\text { pelanggan }\end{array}$ \\
\hline $\begin{array}{l}\text { Input data } \\
\text { keranjang } \\
\text { pesanan, } \\
\text { meliputi nama } \\
\text { menu yang } \\
\text { dipulih, quantity } \\
\text { pesanan, serta } \\
\text { total pesanan. }\end{array}$ & $\begin{array}{l}\text { Data Keranjang } \\
\text { diinputkan oleh } \\
\text { pelanggan } \\
\text { dengan memilih } \\
\text { makanan dan } \\
\text { melakukan } \\
\text { pembayaran ke } \\
\text { cashier. }\end{array}$ & $\begin{array}{l}\text { Data pesanan } \\
\text { dan total } \\
\text { pembayaran }\end{array}$ \\
\hline
\end{tabular}


Desain Sistem

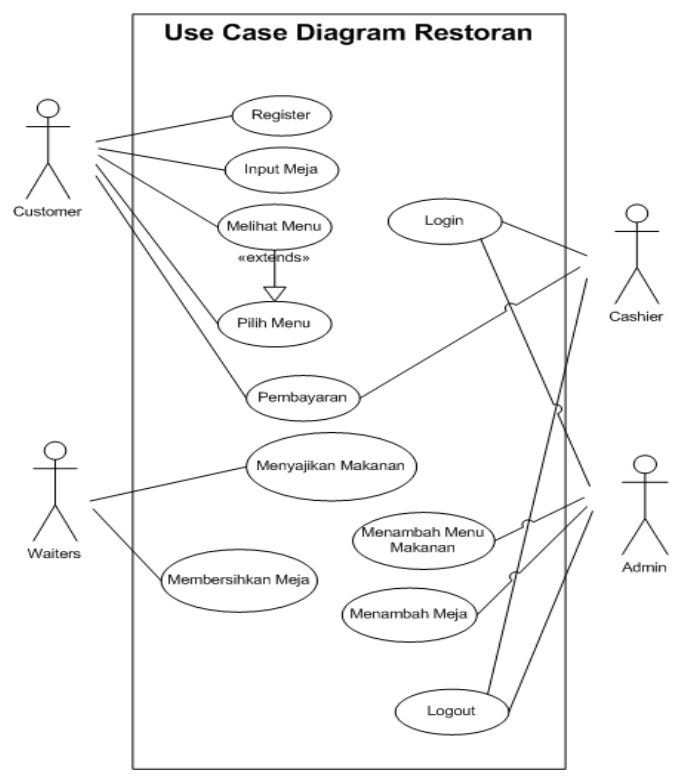

Gambar 1. Use Case Diagram Restoran

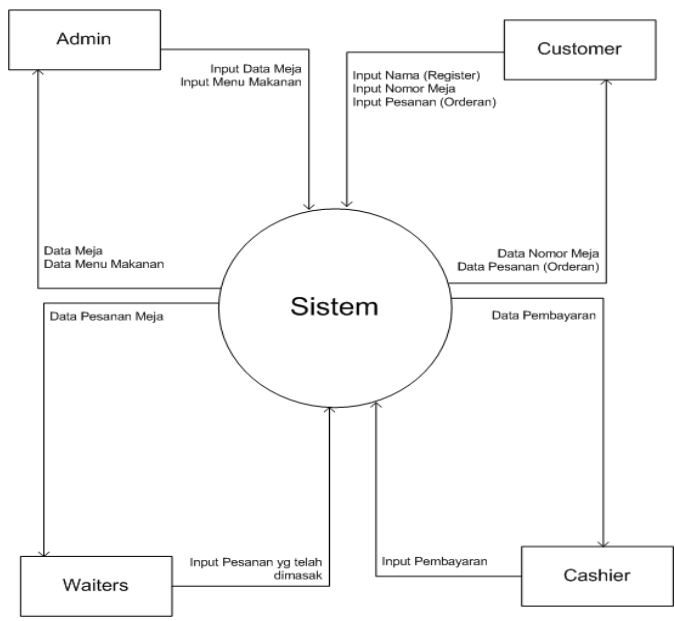

Gambar 2. Context Diagram Sistem Restoran

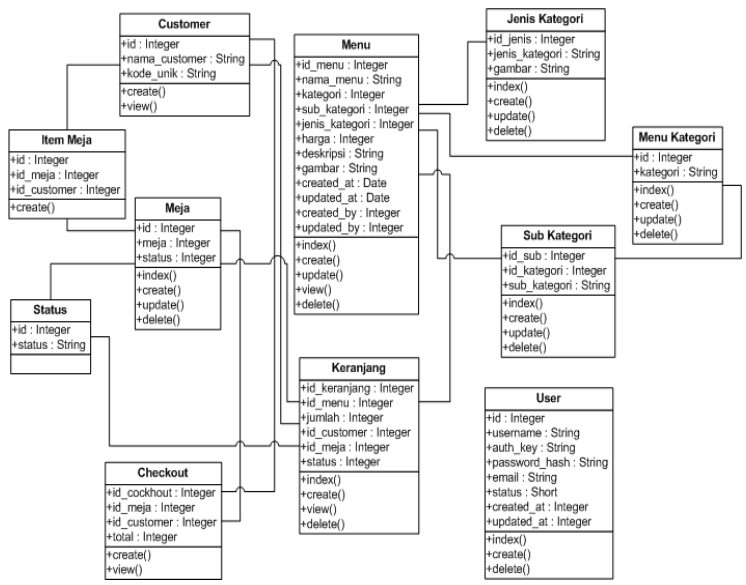

Gambar 3. Class Diagram Restoran
1. Coding dan Implementasi

Pada proses ini kegiatan yang dilakukan adalah menulis bahasa pemrograman dan mendesain keamanan sistem komputer.

a. Desain Interface (Antarmuka)
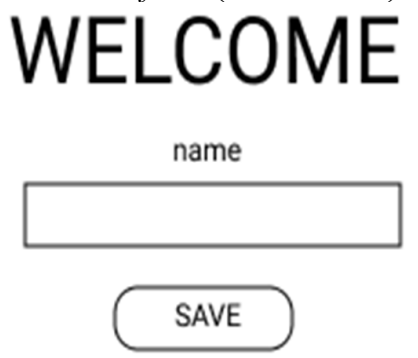

Gambar 4. Desain Interface Customer

CHOOSE YOUR TABLE

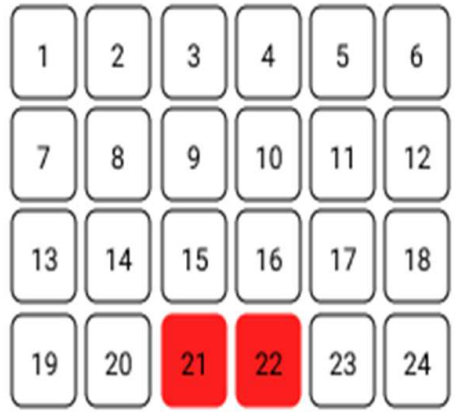

empty $\square$ attend

Gambar 5. Desain Interface Meja Customer

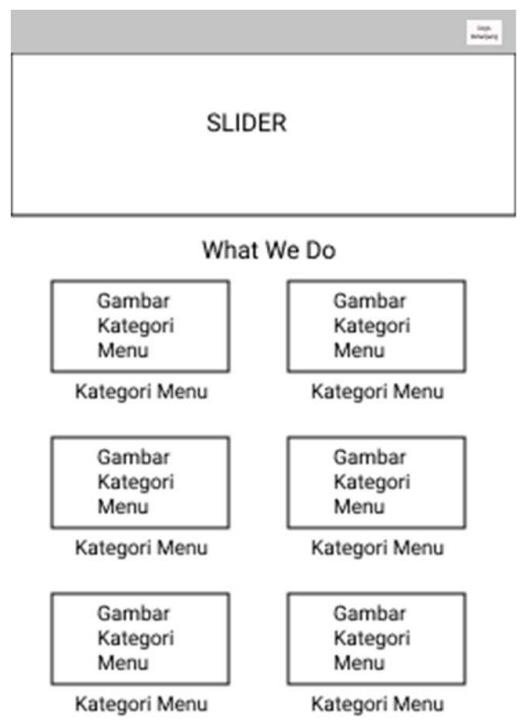

Gambar 6. Desain Interface Menu 
b. Penulisan Program

Program dibuat dan dirancang sesuai dengan desain yang telah ditentukan. Hasil dari rancangan penelitian ini adalah membangun sebuah aplikasi dengan platform, yaitu mobile dan website. Penulisan program dilakukan menggunakan framework yii2 dengan bahasa pemrograman PHP, MySQL sebagai Manajemen Basis Data (Database Management System).

c. Security Sistem

Keamanan sistem harus terjaga demi melindungi data dari pengguna yang tidak diizinkan, sehingga mencegah penyisipan dan penghapusan data (baik manipulasi data dari luar pengetahuan yang diizinkan), diantaranya [2].

a. Autentikasi, penyediaan mekanisme autentikasi, yaitu adanya login dan logout pada sistem untuk pengguna.

b. Autorisasi, berhubungan dengan hak akses yang akan membantu perlindungan data terhadap penggunaan sistem yang tidak diizinkan.

c. Token Based Authentication.

d. Access Control Filter.

e. Role Base Access Control (RBAC).

2. Pengujian (Testing)

Teknik ini digunakan untuk mengkontruksi struktur program melalui pengujian untuk melihat debug, yaitu untuk mengetahui kesalahan atau kerusakan yang terjadi yang menjadikan program tidak dapat berjalan sesuai kebutuhan. Pengujian sistem adalah elemen kritis dari suatu kualitas perangkat lunak yang menjadi suatu jaminan dan mepresentasikan pokok bahasan dari spesifikasi sistem, desain sistem dan pengkodean(coding). Rancangan pengujian sistem dalam penelitian ini, yaitu dengan melakukan pengujian black-box pada seluruh fungsi di dalam sistem.

Pengujian black-box adalah suatu metode pengujian perangkat lunak berfokus dengan persyaratan fungsional dari perangkat lunak.

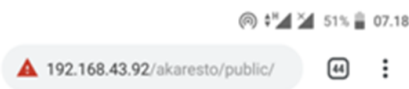

\section{WELCOME}

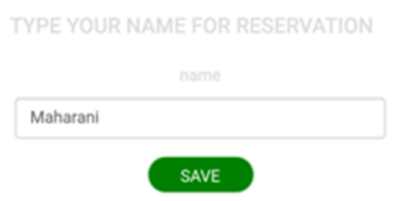

Gambar 7. Halaman Utama Customer

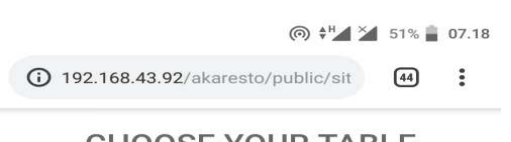

CHOOSE YOUR TABLE

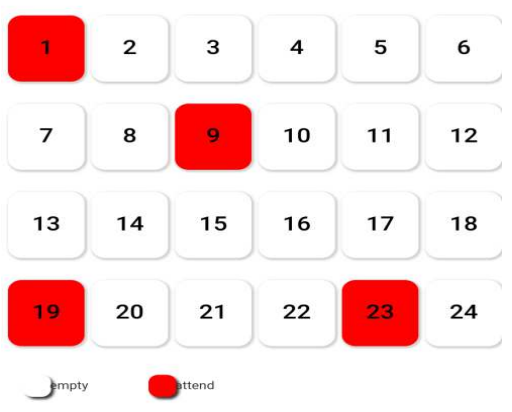

Gambar 8. Pemilihan Meja Customer

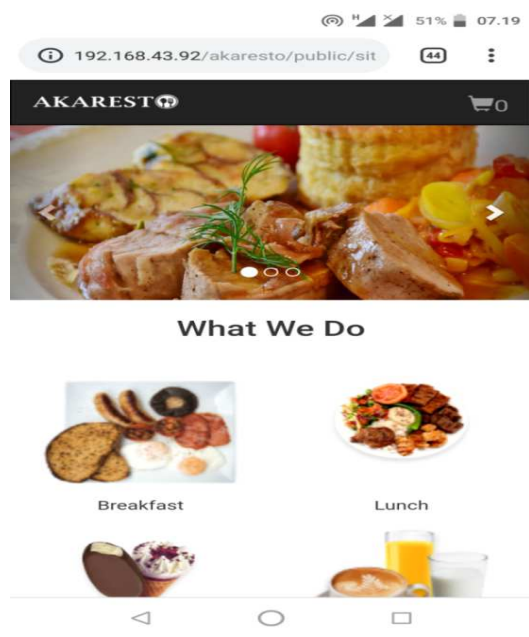

Gambar 9. Halaman Menu Restoran 


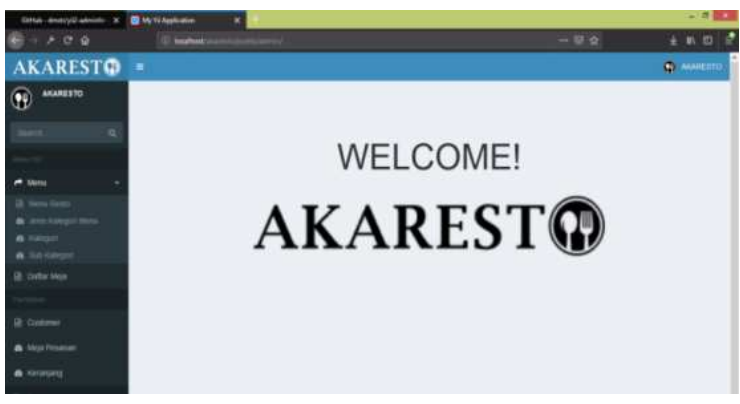

Gambar 10. Halaman Utama Admin

\section{KESIMPULAN}

Berdasarkan tahapan yang dilakukan dalam penelitian ini, diperoleh kesimpulan sebagai berikut :

a. Desain dan rancangan sistem informasi ini dikembangkan dengan mengaplikasikan metode waterfall karena kebutuhan pada restoran telah terdefinisi dengan baik dan jelas.

b. Desain dan rancangan sistem informasi ini akan memberikan informasi yang dapat memudahkan pelanggan/pengunjung restoran dalam memilih meja.

\section{DAFTAR PUSTAKA}

[1] Farell, Geovanne, Hadi Kurnia Saputra, and Igor Novid. "Rancang Bangun Sistem Informasi Pengarsipan Surat Menyurat (Studi Kasus Fakultas Teknik UNP)". Jurnal Teknologi Informasi dan Pendidikan, vol.11, no.2, pp. 55-62, 2018.

[2] Mukhlasin, Hafid. Membangun Aplikasi Profesional Berbasis Web Menggunakan Yii Framework. Buku Baik, Jakarta, 2016.

[3] Silmi, Muhammad, Eko Adi Sarwoko, and Kushartantya Kushartantya. "Sistem Pakar Berbasis Web dan Mobile Web Untuk Mendiagnosis Penyakit Darah Pada Manusia dengan Menggunakan Metode Inferensi Forward Chaining". Jurnal Masyarakat Informatik, vol. 4, no. 7, pp. 31-38, 2013.

[4] Anhar. Panduan Menguasai PHP \& MySQL Secara Otodidak. Media Kita, Jakarta, 2010.

[5] Sasmito, Ginanjar Wiro. "Penerapan Metode Waterfall Pada Desain Sistem Informasi Geografis Industri Kabupaten Tegal”. Jurnal Informatika, vol. 2, no. 1, pp. 6-12, 2017.
[6] Utami, Fei Hari and Asnawati. Rekayasa Perangkat Lunak. Deepublish, Yogyakarta, 2015. 